\title{
The Role of Customer Brand Engagement on Brand Loyalty in the Usage of Virtual Hotel Operator
}

\author{
Susanto Berlin Manarua Situmorang ${ }^{1 *}$, Daniel Tumpal Hamonangan Aruan $^{2}$ \\ ${ }^{1}$ Faculty of Economics and Business, Universitas Indonesia, Jakarta, Indonesia \\ ${ }^{2}$ Faculty of Economics and Business, Universitas Indonesia, Jakarta, Indonesia \\ *Corresponding author. Email: susanto.situmorang@gmail.com
}

\begin{abstract}
Virtual hotel operators have a growing trend in Indonesia during recent years. Two of its main causes is the rise of "budget travelling" and the incentive by the central government to promote tourism industry. Unfortunately, the study of virtual hotel operator itself is still uncommon. The purpose of this study is to explain relationship between the customer brand engagement with attitudinal loyalty and behavioral loyalty from customers in the usage of virtual hotel operators in Indonesia. This research was tested empirically by using PLS-SEM with a sample of 133 respondents, who used hotels operated by virtual hotel operators in Indonesia. The results of this study indicate that sensory experience positively influences customer brand engagement with the virtual hotel operator brand. Furthermore, affective experience positively affects affective and behavioral engagements, whereas intellectual experience positively influences cognitive and affective engagement. Likewise, customer brand engagement can be effective in increasing loyalty, at least on attitudinal level. In addition, attitudinal loyalty positively influences behavioral loyalty on virtual hotel operator. The findings of this study can provide academicians and managers a guide to improve customer engagement and loyalty toward a virtual hotel operator's brand.
\end{abstract}

Keywords: "Customer brand engagement", "Brand experience”, "Attitudinal loyalty”, "Behavioral loyalty", "Virtual hotel operator".

\section{INTRODUCTION}

The rise of tourism industry and the budget travelling phenomenon are few of the many reasons for the growing trend of cheap hotel rooms in Indonesia. This also provides a market for affordable accommodation provider platforms, especially those based on technology or more commonly known as Virtual Hotel Operators (VHO). One of the advantages of VHOs is that they use cutting-edge technology such as big data, machine learning, and artificial intelligence which allows VHOs to carry out dynamic room pricing where hotel room prices are determined by AI or bots automatically based on various available variables. Not only in terms of technology, VHOs have also begun to undergo a transformation by improving services in their virtual hotels by standardizing and marketing determined by the VHO itself. On one report, it was written that the hotel industry is well known for its delay in changing where at this time there are already two types of disruptors that are disrupting the hotel industry, namely, mobile and technological changes that drive these changes and sharing-economy platforms [26]. Several methods have been used by the old hotel industry, one of which is by strengthening the interaction or engagement between hotels and their customers. Researchers have studied this method to then see if it had a good impact on the old hotel industry [1], [2].

Although VHO is a fairly new business model in the world, there are potential problems that can occur for hotels that partner with VHO companies. Director and Head of Research Savills Indonesia Anton Sitorus said that hotels partnering with VHO will collapse when only concerned with numbers, such as room price growth, or additional rooms and expansion. Those who will thrive, therefore, will be the one who have good services. Other study argues that VHO companies must be able to implement strategies that can attract and retain their customers in the long term [3]. Besides that, COVID-19 pandemic that has struck the nations has caused many problems to tourism industry, hospitality 
industry, and to an extent, virtual hotel operators. With the current government advising its citizens not to travel between cities or provinces during this pandemic, it is certain that the hospitality industry will not return to its previous state for a while. As with [1], who used interaction or engagement as one of the methods of the old hotel industry to be able to compete in modern times, the author proposes that customer brand engagement can also be used by VHOs to help not only hotel partners but also VHO companies in competing against competitors in the industry.

Customer engagement and its related issues have always been a consideration and concern of researchers and academics in the marketing world [4]. In particular, Customer Brand Engagement (CBE), as part of Customer Engagement, has a significant influence in the marketing literature [5]. Specifically, the CBE concept has been assumed to be more able to reflect the fundamental nature of the interactive relationship between a brand and consumers [5]. With issues that have already happened or might befall VHO in the future, it is necessary to have research that discusses the relationship between the customer brand engagement with attitudinal loyalty and behavioral loyalty from customers in the usage of virtual hotel operators in Indonesia.

\section{LITERATURE REVIEW}

\subsection{Antecedents of Customer Brand}

\section{Engagement: Brand Experience}

\subsubsection{Sensoric brand experience and customer brand engagement}

Sensory experience is described as a customer's impression of a product or service that is assumed in the human brain and senses. For example, playing in a virtual reality-based video game, visiting an art museum, or tasting local food can invigorate the sensory experience that the customer has. A good visual impression will increase customer engagement by invigorating the senses of customers, shaping them to think about the brand, and increasing their interest in the brand [6]. It's easier to grab a customer's attention when the customer has a good sensory experience. From this, we can build a hypothesis.

H1a. Sensory brand experience has a positive effect on cognitive brand engagement.
One study stated that customer sensory experiences can influence customer interest, which indicates a strong layer of thrill and individual interest concerning the focus of engagement on brands [7]. Emotional engagement is connected to customer affection and positive fondness for the VHO brand. Therefore, we can construct the next hypothesis.

H1b. Sensory brand experience has a positive effect on affective brand engagement.

In the tourism and hospitality industry, service providers will focus on administering and appealing sensory experiences, including smell, taste, sight, and touch [22]. Customer experience with service brands can affect the level of customer engagement with the brand [8]. Behavioral engagement is akin to the extent to which customers will spend "energy, effort, and time" on brands in interactions with these brands [9]. This indicates that when customers are contented with their sensory experience, they tend to engage again in carrying out activities related to the brand. From this we can build the next hypothesis.

H1c. Sensory brand experience has a positive effect on behavioral brand engagement.

\subsubsection{Affective brand experience and customer brand engagement}

Brand experience has an affective relationship with customer feelings, which is produced as a result of an emotional affiliation with a brand [10]. Other study stated that customer affective conditions, including positive and negative feelings, can affect customer brand engagement [11]. Customers will have a strong affective experience when they perceive comfortable with the hotel's conditions that they live in. Emotional experiences can intensify customer emotions by invigorating joy and excitement [22]. Therefore, positive affective experiences can be useful in increasing customer's enthusiasm in the brand. Then we can make the following hypothesis.

H2a. Affective brand experience has a positive effect on cognitive brand engagement.

A customer's affective experience can be correlated with the emotional element of the experience. Customer engagement from an emotional viewpoint has been widely associated with affective engagement [9]. In addition, the positive feelings developed by the VHO brand will increase the customer's emotional bond with the brand. Then we can construct the following hypothesis.

H2b. Affective brand experience has a positive effect on affective brand engagement. 
The customer experience can be positive or negative, and the feedback from customers can be predicted positively if the customer is satisfied with customer service including from the hotel. A pleasant and comfortable feeling will be the motivation to engage in behavioral engagement with the VHO brand. The growth of a strong affection for the experience of staying at a hotel with VHO brand, will result in a positive customer engagement with the use of VHO branded hotel services in the future [1].

H2c. Affective brand experience has a positive effect on behavioral brand engagement.

\subsubsection{Behavioral brand experience and customer brand engagement}

Behavioral brand experience leads to physical experiences caused by interactions between customers and brands [22]. Customers can encounter such bodyoriented experiences because of the facilities each hotel has. When customers are contented with certain activities, they will want to review information that is akin to the brand, such as information on facilities, travel options, and others. The general assertion argues that behavioral experiences can bolster customer engagement cognitively.

H3a. Behavioral brand experience has a positive effect on cognitive brand engagement.

Engagement is affectively related to the emotional level that are felt by customer behavioral experiences. The experience resulting from using the facilities provided by the hotel can nurture an emotional connection between the customer and the brand. From this we can construct the following hypothesis.

H3b. Behavioral brand experience has a positive effect on affective brand engagement.

Behavioral experiences relate to the physical activity of the customer generated by the brand, which leads to physical engagement with the brand and activities associated with that brand. Affective engagement can provide a basis for comfort in maintaining relationships and developing emotional bonds with brands. This kind of engagement can be altered by customer perceptions of behavioral experiences at VHO branded hotels. From this we can form a hypothesis.

H3c. Behavioral brand experience has a positive effect on behavioral brand engagement.

\subsubsection{Intellectual brand experience and customer brand engagement}

Experiential marketing uses promotional exercises that are devised to interact with customers, brands, and communities, and provide opportunities to engage in different travel activities. Thus, the intellectual integrated resort experience raises the level of customer engagement [1]. In addition, leisure activities can spur the logical thinking process of customers. Therefore, the customers can gain a higher intellectual experience, which in turn, can give the customers a sense of identity and a relationship with the brand. Hypotheses can then be formed.

H4a. Intellectual brand experience has a positive effect on cognitive brand engagement.

A study that inspected the direct and indirect impact of brand experiences including intellectual experiences on affective commitment [12]. Likewise, other study found that convergent and divergent intellectual experience thinking is related to place attachment [13]. Therefore, when customers are satisfied with the intellectual brand experience, they can establish an emotional connection with the VHO brand.

H4b. Intellectual brand experience has a positive effect on affective brand engagement.

The customer's intellectual experience is seen as a precursor to behavioral engagement. One study stated that customers' intellectual experiences such as utilizing mobile applications for travel activities affect behavioral engagement [14]. Customers who experience positive intellectual experiences, they tend to connect behaviorally with integrated resort brands.

H4c. Intellectual brand experience has a positive effect on behavioral brand engagement.

\subsection{Customer Brand Engagement}

One study refers customer brand engagement as a condition of customer motivation, brand-related, and context-related characteristics characterized by specific levels, namely cognitive activity, affective activity, and behavioral activity [1]. The level of brand engagement which includes cognitive, affective, and behavioral can predict loyalty [1]. This study will use three main dimensions / keys, namely cognitive, affective, and behavioral aspects established on previous literature [5], [15], [16]. The results of customer brand engagement are satisfaction, loyalty, commitment, and trust [17]. Researchers have described customer engagement as a 
psychological process that encourages customer loyalty [8].

Understanding the process by which brands influence customer's behavioral intentions towards brands is important, because it is an indicator of actual consumption behavior [25]. One study conceptualized four divisions of behavioral loyalty: word-of-mouth, purchase intention, price sensitivity, and complaining behavior. Thus, customer brand engagement can influence brand-related outcomes such as attitudinal loyalty and behavioral loyalty. In this study, cognitive, affective, and behavioral engagement comes from customer assessments of an experience (sensory, affective, intellectual, and behavioral). Customer engagement can be considered as the antecedent potential of repeated purchases (behavioral loyalty) driven by strong internal dispositions over a period of time [8]. We can then construct a hypothesis from the above explanation.

H5a. Cognitive brand engagement has a positive effect on attitudinal loyalty.

H5b. Cognitive brand engagement has a positive effect on behavioral loyalty.

H6a. Affective brand engagement has a positive effect on attitudinal loyalty.

H6b. Affective brand engagement has a positive effect on behavioral loyalty.

H7a. Behavioral brand engagement has a positive effect on attitudinal loyalty.

H7b. Behavioral brand engagement has a positive effect on behavioral loyalty.

\subsection{Attitudinal Loyalty and Behavioral Loyalty}

One study defines loyalty as "a deeply-held predisposition to repatronize a preferred brand or service consistently in the future, causing repetitive same brand purchasing, despite situational influences and marketing efforts having the potential to cause switching behavior" [24]. It is concluded that it is a tendency or intention held firmly by the customer to continue to use the brand or service in the future, regardless of the marketing attempts of the brand's competitors trying to cause a change in behavior. A study view loyalty as an attitude- behavior relationship and identify the effect of attitude towards behavior in the customer loyalty framework [18].

H8. Attitudinal loyalty has a positive effect on behavioral loyalty.

On the basis of the above hypotheses, this study proposes the model shown in Figure 1.

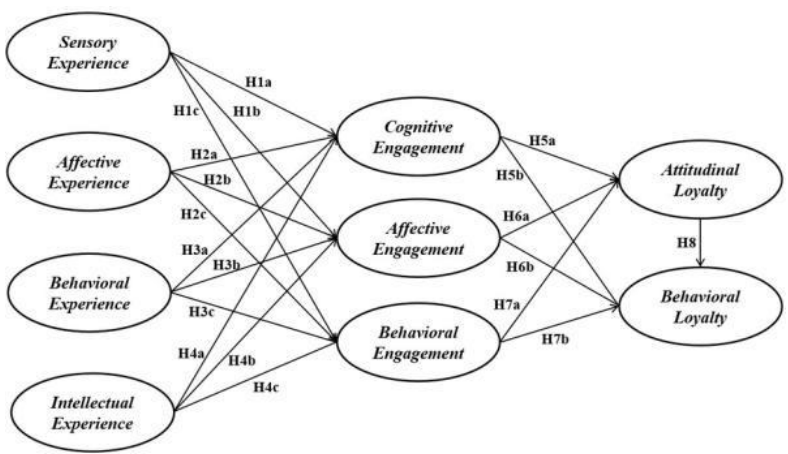

Figure 1. Research Model and Hypothesis.

\section{METHODOLOGY}

Table 1. Measurement Model Results

\begin{tabular}{|l|c|c|c|l|}
\hline Variables & $\begin{array}{c}\text { Cronbach' } \\
\text { s Alpha }\end{array}$ & CR & AVE & $\begin{array}{c}\text { Outer } \\
\text { Loading }\end{array}$ \\
\hline $\begin{array}{l}\text { Affective } \\
\text { Engagement }\end{array}$ & 0,855 & 0,91 & 0,77 & $\begin{array}{l}\text { AEG1: } 0,903 \\
\text { AEG2: } 0,897 \\
\text { AEG3: } 0,842\end{array}$ \\
\hline $\begin{array}{l}\text { Affective } \\
\text { Experience }\end{array}$ & 0,908 & $\begin{array}{c}2,94 \\
2\end{array}$ & $\begin{array}{c}0,84 \\
5\end{array}$ & $\begin{array}{l}\text { AE1: } 0,88 \\
\text { AE2: } 0,943 \\
\text { AE3:0,934 }\end{array}$ \\
\hline $\begin{array}{l}\text { Attitudinal } \\
\text { Loyalty }\end{array}$ & 0,906 & 0,93 & $\begin{array}{c}0,72 \\
6\end{array}$ & $\begin{array}{l}\text { AL1: } 0,819 \\
\text { AL2: } 0,853 \\
\text { AL4: } 0,83 \\
\text { AL5: } 0,88\end{array}$ \\
\hline $\begin{array}{l}\text { Behavioral } \\
\text { Engagement }\end{array}$ & 0,846 & 0,90 & $\begin{array}{c}0,76 \\
5\end{array}$ & $\begin{array}{l}\text { BEG1: } 0,805 \\
\text { BEG2: } 0,894 \\
\text { BEG3: } 0,92\end{array}$ \\
\hline $\begin{array}{l}\text { Behavioral } \\
\text { Experience }\end{array}$ & 0,933 & 0,95 & 0,88 & $\begin{array}{l}\text { BE1: } 0,948 \\
\text { BE2: } 0,957 \\
\text { BE3: } 0,911\end{array}$ \\
\hline $\begin{array}{l}\text { Behavioral } \\
\text { Loyalty }\end{array}$ & 0,844 & 0,89 & 5 & 0,68 \\
1 & $\begin{array}{l}\text { BL1: } 0,775 \\
\text { BL2: } 0,825 \\
\text { BL3: } 0,864 \\
\text { BL4: } 0,833\end{array}$ \\
\hline $\begin{array}{l}\text { Cognitive } \\
\text { Engagement }\end{array}$ & 0,878 & 0,92 & 5,80 & $\begin{array}{l}\text { CEG1: } 0,886 \\
\text { CEG2: } 0,914 \\
\text { CEG3: } 0,889\end{array}$ \\
\hline $\begin{array}{l}\text { Intellectual } \\
\text { Experience }\end{array}$ & 0,872 & 0,92 \\
1 & 0,93 & 0,83 & $\begin{array}{l}\text { IE1: } 0,899 \\
\text { IE2: } 0,897 \\
\text { IE3: } 0,88\end{array}$ \\
\hline $\begin{array}{l}\text { Sensoric } \\
\text { Experience } 0,894 \\
\text { SE2: } 0,916 \\
\text { SE3: } 0,934\end{array}$ \\
\hline
\end{tabular}




\subsection{Research Strategy}

Data collection had been done through quantitative data collection. This data collection was carried out through an online questionnaire. The sample in this study were virtual hotel operators who filled out the questionnaire from this study. In all, 133 respondents fit the criteria set by our standards. The survey begins with an explanation of virtual hotel operators along with examples of virtual hotel operator companies operating in Indonesia. Then, the respondent was directed to answer the question "Have you ever visited a hotel operated by a Virtual Hotel Operator (VHO) in at least one of the following VHO brands in the last 1 (one) year?". If the respondent answers "Yes", then the respondent is directed towards screening questions where the respondent must answer questions about the frequency of hotel use operated by virtual hotel operators during the last 12 months, the names of virtual hotel operators that have been used and the names of virtual hotel operators that are most frequently used. After answering these questions, the respondents were directed to answer the research survey, which includes all variables that are being tested in this study. VHO's brands that are most frequently used by the respondents was embedded on the brand-related questions. After the respondent has answered all the questions in the research questionnaire, the respondent was directed to fill in the respondent self-profile.
In the data analysis process, the authors used VarianceBased Structural Equation Modeling or also known as Partial Least Square (PLS). PLS tests measurement models and structural models that can handle all types of data, from non-metrics to metrics with minimal assumptions and PLS can handle both reflective and formative constructs [23]. The PLS modeling is applicable for this study as it can be applied in the estimation of complex models with relatively small sample sizes [19]. Researchers chose to use SmartPLS software because SmartPLS has a good user interface graphic and can make users estimate the PLS path model [23].

\subsection{Measurement Model}

Measurement model analysis aims to determine whether the indicators of the construct are feasible to later be used to measure the desired constructs and the internal consistency of these indicators. Based on the results that can be seen in Table 1, it is found that the Cronbach alpha value for each variable is above 0,6 and the composite reliability (CR) value is above 0,7 . This indicates that all items used to measure each construct are reliable [23]. In addition, the average variance extracted (AVE) value of all variables has exceeded 0,5

[23]. Therefore, it implies that the variables and indicators used in this study are valid. It was also found that each indicator already has the largest loading value on the variables associated with it and the highest loading that a latent variable has come from the indicators related to it [23]. The FornellLarcker

\subsection{Data Analysis}

Table 2.Loyalty1,8620,031H7b: AcceptedAttitudinal Loyalty -> Behavioral Loyalty6,5240H8: Accepted FornellLarcker Criterion

\begin{tabular}{|l|c|c|c|c|c|c|c|c|c|}
\hline \multicolumn{1}{|c|}{ Variables } & AEG & AE & AL & BEG & BE & BL & CEG & IE & SE \\
\hline Affective Engagement & 0,89 & & & & & & & & \\
\hline Affective Experience & 0,622 & 0,911 & & & & & & & \\
\hline Attitudinal Loyalty & 0,798 & 0,585 & 0,852 & & & & & & \\
\hline Behavioral Engagement & 0,643 & 0,533 & 0,746 & 0,891 & & & & & \\
\hline Behavioral Experience & 0,476 & 0,457 & 0,364 & 0,273 & 0,918 & & & & \\
\hline Behavioral Loyalty & 0,739 & 0,564 & 0,844 & 0,696 & 0,326 & 0,818 & & & \\
\hline Cognitive Engagement & 0,651 & 0,539 & 0,551 & 0,412 & 0,501 & 0,535 & 0,88 & & \\
\hline Intellectual Experience & 0,586 & 0,525 & 0,478 & 0,326 & 0,528 & 0,458 & 0,801 & 0,889 & \\
\hline Sensoric Experience & 0,516 & 0,579 & 0,49 & 0,437 & 0,311 & 0,502 & 0,49 & 0,429 & 0,916 \\
\hline
\end{tabular}

Table 3. Structural Model Results

PathT-valuesP-valuesResultsSensoric Experience -> Cognitive Engagement2,7360,003H1a: AcceptedSensoric Experience -> Affective Engagement2,6180,004H1b: AcceptedSensoric Experience -> Behavioral Engagement2,0010,023H1c: AcceptedAffective Experience -> Cognitive Engagement1,0170,155H2a: RejectedAffective Experience -> Affective Engagement2,7810,003H2b: AcceptedAffective Experience -> Behavioral Engagement4,1590H2c: AcceptedBehavioral Experience -> Cognitive Engagement0,6940,244H3a: RejectedBehavioral Experience -> Affective 


\footnotetext{
Engagement1,3730,085H3b: RejectedBehavioral Experience -> Behavioral Engagement0,50,309H3c: RejectedIntellectual Experience -> Cognitive Engagement7,4330H4a: AcceptedIntellectual Experience -> Affective Engagement3,9680H4b: AcceptedIntellectual Experience -> Behavioral Engagement0,6110,271H4c: RejectedCognitive Engagement -> Attitudinal Loyalty1,7520,04H5a: RejectedCognitive Engagement -> Behavioral Loyalty0,3020,381H5b: RejectedAffective Engagement -> Attitudinal Loyalty6,0690H6a: AcceptedAffective Engagement -> Behavioral Loyalty1,5330,063H6b: RejectedBehavioral Engagement -> Attitudinal Loyalty4,7450H7a: AcceptedBehavioral Engagement -> Behavioral
}

Criterion compares the square root of the AVE value with the latent variable correlation which can be seen in Table 2. It can be concluded that the discriminant validity test has been successfully carried out [23].

\subsection{Structural Model}

The structural model provides outcomes on experimenting the hypothesized model. The significance level of hypothesized relationships can be said to be significant with the value of t-value $>1,645$, as the hypotheses are one-tailed. The significance, sign and magnitude of the path coefficients are shown in Table 3. From nineteen hypotheses, thirteen were supported as their t-values are greater than 1,645. Seven hypotheses were rejected as their t-values are lower than 1,645.

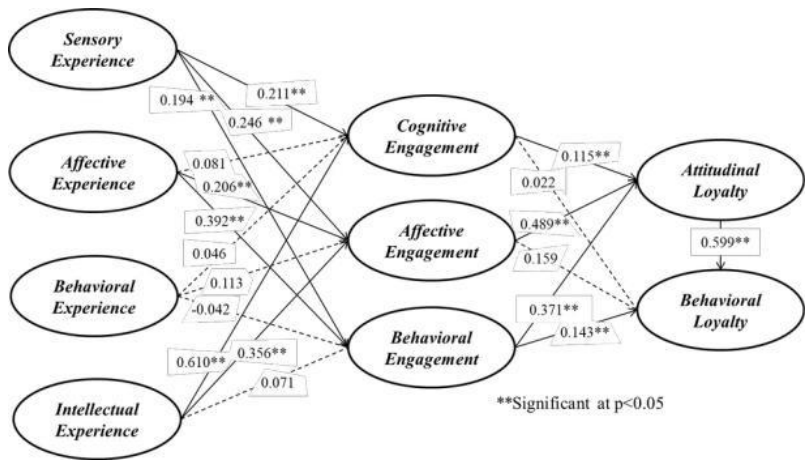

Figure 2. Final Structural Model Output.

\section{RESULT AND DISCUSSION}

Sensory experience was found to positively affect cognitive engagement, affective engagement, and behavioral engagement. This aligned with a study that stated that a good visual impression increases customer engagement by encouraging the senses of customers, making them think about the brand, and increasing their interest in the brand [6]. Other research also states that these sensory experiences spur positive emotions from customers, such as satisfaction, pleasure, and happiness [17]. The VHO brand that gives a strong sensory impression positively affect its customer's positive thinking about the VHO's brand, happiness or feelings, and behavior of staying more often at the VHO compared to hotels operated by competitors, while using VHO services or engaging with the VHO's brand. VHO should use this information to formulate strategies that can exploit this in order to further enhance its positive engagement with its customers.

Affective experience was found to not affect cognitive engagement, while also positively affecting affective engagement and behavioral engagement. The results of this test are different from one study, in which he argues that the affective conditions of customers, including positive and negative feelings, can affect customer brand engagement, or in this case cognitive engagement [11]. The result however aligns with one study that also views customer engagement from a psychological perspective that has been associated with affective engagement [9]. This implies that feelings or sentiments that arise inside customer's minds, because of the VHO's brand, have a positive impact on building positive feelings from customers generated from the VHO's brand or its tendency to use the VHO service more often, when using the VHO's service.

Behavioral experience was found to not positively affect cognitive engagement, affective engagement, and behavioral engagement. Previous studies also have found the same results. This result aligns with one study that found that behavioral experience did not have a positive effect on cognitive engagement [1]. This results however, isn't in line with one research wherein the research revealed that a superior brand experience produces a stronger emotional response and, in the end, results in commitment and satisfaction with the brand concerned [12]. The results indicate that customer's behavioral involvement when using these VHO services does not have a positive impact on making customers think about the VHO's brand; affecting customer's happiness or its pride; or influencing customer's behavioral engagement when they use the VHO's brand services. VHO shouldn't focus on developing its customer's behavioral experience and must turn its attention on other construct of brand experiences.

Intellectual experience was found to positively affect cognitive engagement and affective engagement, while also not positively affecting behavioral engagement. One study found that intellectual experiences affect customer brand engagement [1]. This result didn't align with one study that said a customer's intellectual 
experience such as using a mobile application for travel activities can influence behavioral engagement [14]. When customers think about the VHO's brand while using VHO's services, this raises customer's happiness and grow its interest in learning about the VHO brand when they use the VHO's services.

Cognitive engagement was found to positively influences attitudinal loyalty, while also didn't positively influencing behavioral loyalty. This conclusion is in accordance with the findings in one research [20], where he found that there was a nonpositive relationship between cognitive processing brand engagement and brand loyalty. This indicates that customers who think about this virtual hotel operator brand or have a growing interest in learning about the VHO's brand, felt that this VHO can be trusted and capable enough to meet customer's needs but still not enough to become its first choice in the future. Furthermore, affective engagement was found to positively influences attitudinal loyalty, while also didn't positively influencing behavioral loyalty. Researchers have described customer engagement as a psychological process that encourages customer loyalty [8].

A study can explain this result where it was found that affective engagement has a positive effect on brand loyalty [20]. Customers who felt happiness when using VHO's services tend to felt that the VHO can be trusted to fulfill their needs and satisfaction, but also still not enough to lure customers to use the operator's virtual hotel services in the future. Further actions must be taken by VHO to insure customer's behavioral loyalty.

On the other hand, behavioral engagement was found to has a positive effect on attitudinal loyalty and behavioral loyalty. This can be explained by the findings in one research, where it was found that there was a positive relationship between activation of brand engagement and brand loyalty [20]. This result also aligns with one study, which state that the results of customer brand engagement are satisfaction, loyalty, commitment, and trust [17]. The frequent use of hotel operator virtual services by the customers has a positive effect on loyalty to the virtual hotel operator so that the VHO's brand can the most trusted and most capable of fulfilling customer needs, while also becoming the first choice when customers want to use the operator's virtual hotel services in the future.

Attitudinal loyalty was found to have positive effect on behavioral loyalty. This result aligns with a study that view attitudinal loyalty as a driving forces of behavioral loyalty [18], [21]. Customers who felt that
VHO can be trusted to fulfill their needs and satisfaction tend to continue in using this VHO for years in the future and even give positive picture to its friends and families.

moderator or admin who can respond customer's questions or complaints will make customers feel involved in the service development process of the VHO.

\section{CONCLUSIONS AND IMPLICATIONS}

The main purpose of this research is analyze the effect of the relaionship between the experiences of using virtual hotel operators by customers on customer brand engagement and the effect of the relationship between customer brand engagement on brand loyalty from customers of VHO. This study has found that attitudinal loyalty influences behavioral loyalty. Managers can exploit this finding by providing rewards to customers who have become a long-time user of the VHO's brands. The rewards can be in the form of discounts, rebates, or incentive programs. Customer tier is one of the methods that can be used in implementing the reward system. On this pandemic state, the reward system can be one of the major tools in ensuring customers to keep using the brand. The findings also suggest that brand engagement can be effective in increasing loyalty, at least in attitudinal level. VHO, therefore, should build an everlasting customer-brand relationship with the aim of increasing loyalty. Building good relationships between hotel staff and customers could results in customers that more comfortable and happier so that the services delivery will be more effective in meeting customer needs. For example, in the state of pandemic, giving mask or hand sanitizer as a sign of goodwill, will not only build the customer- staff relationship, but also ensure that customer will feel secured and safe, which then result in more trust by the customer toward the VHO.

As it implied that sensory experience has influence on customer brand engagement, VHO companies must create marketing strategies that could enhance the visual experience of customers. This can be achieved by creating an atmosphere in the hotel's rooms or in the lobby that can convey the characteristics of the virtual hotel operator's brand, whether in terms of color, sound/ music, or exterior and interior design. The sensory experience that is delivered by each virtual hotel operator's partner hotel may also be inspired by the location of the hotel to show the characteristics of local tourism. For example, using Bali architecture for the lobby space while using the brand's color as its main 
color for all hotels that are located in Bali. In addition, affective experience plays a key role on affective and behavioral engagement; as well as intellectual experience which have a positive influence on affective and cognitive engagements. VHO can exploit this finding by building an online brand community filled with customers who use the VHO's brand. Customers can provide their opinions or memories when using certain VHO services in different locations. It can also stimulate curiosity from customers about the operator hotel virtual brand. In addition, having a moderator or admin who can respond customer's questions or complaints will make customers feel involved in the service development process of the VHO.

\section{AUTHORS' CONTRIBUTIONS}

S.B.M.S. carried out the experiment. D.T.H.A. supervised the whole process and the findings of this work. Both authors provided critical feedback and helped shape the research and analysis of this work.

\section{ACKNOWLEDGMENTS}

This research would not have been possible without the support of my supervisor, Daniel Tumpal Hamonangan Aruan, PhD. His knowledge, experiences, and attention to detail kept my work on track from the beginning until the final draft of this research.

\section{REFERENCES}

[1] J. Ahn and K. J. Back, "Antecedents and consequences of customer brand engagement in integrated resorts," Int. J. Hosp. Manag., vol. 75, no. November 2017, pp. 144-152, 2018, doi: 10.1016/j.ijhm.2018.05.020.

[2] R. Touni, W. G. Kim, H. M. Choi, and M. A. Ali, "Antecedents and an Outcome of Customer Engagement With Hotel Brand Community on Facebook," J. Hosp. Tour. Res., vol. 44, no. 2, pp. 278299, 2020, doi: 10.1177/1096348019895555.

[3] D. Dharmayanti and S. Prasojo, "Analisa Pengaruh Digital Marketing Terhadap Brand Advocacy Dengan Perceived Service Quality Dan Customer Engagement Sebagai Variabel Intervening," 2016.

[4] R. Algharabat, N. P. Rana, A. A. Alalwan, A. Baabdullah, and A. Gupta, "Investigating the antecedents of customer brand engagement and consumer-based brand equity in social media," J. Retail. Consum. Serv., vol. 53, no. October 2018,

p. 101767,2020 , doi:

10.1016/j.jretconser.2019.01.016.

[5] L. D. Hollebeek, M. S. Glynn, and R. J. Brodie, "Consumer brand engagement in social media:
Conceptualization, scale development and validation," $J$. Interact. Mark., vol. 28, no. 2, pp. 149-165, 2014, doi: 10.1016/j.intmar.2013.12.002.

[6] W. Öhman, "Instagram Marketing: A Study About The Effect of Visual Content On Customer Engagement In The Airline Industry,” pp. 1-70, 2017, [Online]. Available: https://skemman.is/bitstream/1946/28664/1/MIB06 17_Thesis_Wilhelm_Öhman_Customer_Engagem ent_On_Instagram_The_Effet_Of_Visual_Content.pdf.

[7] K. K. F. So, C. King, and B. Sparks, "Customer Engagement With Tourism Brands: Scale Development and Validation," J. Hosp. Tour. Res., vol. 38, no. 3, pp. 304-329, 2014, doi: $10.1177 / 1096348012451456$.

[8] J. Bowden, "The process of customer engagement: A conceptual framework," J. Mark. Theory Pract., vol. 17, no. 1, pp. 63-74, 2009, doi: 10.2753/MTP1069-6679170105.

[9] L. D. Hollebeek, "Demystifying customer brand engagement: Exploring the loyalty nexus," J. Mark. Manag., vol. 27, no. 7-8, pp. 785-807, 2011, doi: 10.1080/0267257X.2010.500132.

[10] L. Zarantonello and B. H. Schmitt, "Using the brand experience scale to profile consumers and predict consumer behaviour," J. Brand Manag., vol. 17, no. 7, pp. 532-540, 2010, doi: $10.1057 / \mathrm{bm} .2010 .4$

[11] N. Garg, J. Inman, and V. Mittal, "Incidental and task-related affect: A re-inquiry and extension of the influence of affect on choice," J. Consum. Res., vol. 32, no. 1, pp. 154-159, 2005, doi: $10.1086 / 426624$.

[12] O. Iglesias, J. J. Singh, and J. M. Batista-Foguet, "The role of brand experience and affective commitment in determining brand loyalty," $J$. Brand Manag., vol. 18, no. 8, pp. 570-582, 2011, doi: $10.1057 / \mathrm{bm} .2010 .58$.

[13] P. R. Bendel, "Branding New York City-the saga of 'i love New York," City Brand. Theory Cases, pp. 179-183, 2010, doi: 10.1057/9780230294790.

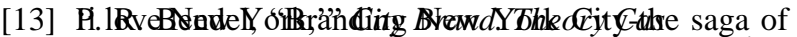

[14] J. Fang, Z. Zhao, C. Wen, and R. Wang, "Design and performance attributes driving mobile travel application engagement," Int. J. Inf. Manage., vol. 37, no. 4, pp. 269-283, 2017, doi: 10.1016/j.ijinfomgt.2017.03.003.

[15] A. B. Bakker, J. J. Hakanen, E. Demerouti, and D. Xanthopoulou, "Job resources boost work engagement, particularly when job demands are high," J. Educ. Psychol., vol. 99, no. 2, pp. 274- 284, 2007, doi: 10.1037/0022-0663.99.2.274. 
[16] A. M. Klem and J. P. Connell, "Relationships matter: Linking teacher support to student engagement and achievement," J. Sch. Health, vol. 74, no. 7, pp. 262-273, 2004, doi: 10.1111/j.17461561.2004.tb08283.x.

[17] R. J. Brodie, L. D. Hollebeek, B. Jurić, and A. Ilić, "Customer engagement: Conceptual domain, fundamental propositions, and implications for research," J. Serv. Res., vol. 14, no. 3, pp. 252- 271, 2011, doi: 10.1177/1094670511411703.

[18] A. S. Dick and K. Basu, "Customer loyalty: Toward an integrated conceptual framework," $J$. Acad. Mark. Sci., vol. 22, no. 2, pp. 99-113, 1994, doi: 10.1177/0092070394222001.

[19] J. Henseler, C. M. Ringle, and R. R. Sinkovics, "The use of partial least squares path modeling in international marketing," Adv. Int. Mark., vol. 20, no. 2009 , pp. 277-319, 2009, doi: 10.1108/S14747979(2009)0000020014.

[20] C. Leckie, M. W. Nyadzayo, and L. W. Johnson, "Antecedents of consumer brand engagement and brand loyalty," J. Mark. Manag., vol. 32, no. 5-6, pp. $\quad 558-578,2016$, doi: 10.1080/0267257X.2015.1131735.
[21] S. Saini and J. Singh, “A Link Between Attitudinal and Behavioral Loyalty of Service Customers," Bus. Perspect. Res., vol. 8, no. 2, pp. 205-215, 2020, doi: $10.1177 / 2278533719887452$.

[22] B. Schmitt, "Experiential Marketing”. Journal of Marketing Management, 15(1-3), 53-67, 1999. doi:10.1362/026725799784870496

[23] J. F. Hair Jr, W. C. Black, B. J. Babin, R. E. Anderson, "Multivariate Data Analysis." Pearson Education Inc., NJ, 2010.

[24] R. L. Oliver, "Whence customer loyalty?” Journal of Marketing, 63, 33-44, 1999.

[25] V. A. Zeithaml, L. L. Berry, \& A. Parasuraman, "The behavioral consequences of service quality." Journal of Marketing, 60(2), 31-46, 1996 Retrieved from http://www.jstor.org/stable/1251929

[26] Revenue Strategy Summit, "Two digital disruptors hurting hotels," Hotel News Now, July 30 , 2015. [Online]. Available: http://www.hotelnewsnow.com/articles/27236/Two digitaldisruptors-hurting-hotels.30 July 2015 (Accessed August 16, 2020) 